\title{
Enduring or Crossing Distance for Love? Negotiating Love and Distance in the Lives of Mixed Transnational Couples
}

\author{
by Rebecca Chiyoko King-O'Riain \\ National University of Ireland Maynooth
}

Sociological Research Online, 21 (1), 12

$<\mathrm{http}: / /$ www.socresonline.org.uk/21/1/12.html>

DOI: $10.5153 /$ sro.3804

Received: 26 Feb 2014 | Accepted: 28 Aug 2015 | Published: 28 Feb 2016

\begin{abstract}
Within the field of transnationalism and globalization, studies have tended to focus on the flow of people, ideas and goods ( Giddens 2003, Beck 2011, Fitzgerald 2008). Within the field of migration this has meant importantly an increasing focus on studies of gender, migration and emotion (Brooks and Simpson 2013; Svasek and Skrbis 2007, Baldassar 2008). However, these studies tend to focus on the context of migration and how that shapes decisions around migration and belonging without focusing on the effect of migration on emotions themselves. Through ethnographic narrative interviews with 36 mixed transnational couples, this article analyses how the emotion of love is understood and practiced within some 'global families' (Beck and Beck-Gernsheim 2014). The article finds that for the mixed intercultural couples interviewed here, distance played a role in defining and confirming love (love at a distance) and was often seen as a reason to migrate or move (crossing distance for love) as a test or proof that love was real. These different cultural meanings of love show how distance could increasingly play a role in how we define and practice love today.
\end{abstract}

\section{Keywords: Transnationalism, Emotion, Distance, Love, Globalization}

1.1 To date, studies of transnationalism and globalization have tended to focus on the flow of people, ideas and goods (Giddens 2003, Beck 2011, Fitzgerald 2008). Within the field of migration this has also brought a welcome increased focus on gender, migration and emotion (Brooks and Simpson 2013; Svasek and Skrbis 2007, Baldassar 2008). However, these studies tend to focus on the context of migration and how it shapes decisions around migration and belonging without focusing on the effect of migration on emotions themselves. This article examines the understandings and practices of romantic love in relation to geographic distance within transnational couples. The article first positions itself within the literature on transnationalism and emotion. It then proceeds to explain the methods used, which were ethnographic narrative interviews with 36 mixed transnational couples, in order to understand and analyse how the emotion of love is understood and practiced within some 'global families' (Beck and Beck-Gernsheim 2014). Finally, the article discusses its conclusions and finds that emotions serve as the basis for reflective processes, which can lead to taking social action (migrating for love). For the couples interviewed here, distance played a role in defining and confirming love (love at a distance) and was often seen as a reason to migrate or move (crossing distance for love) as a test or proof that love was real. These different cultural meanings of love show how distance could increasingly play a role in how we define and practice love today.[1]

\section{Understandings and Practices of Love in Mixed Transnational Couples}

2.1 Transnational families, like many of us, function in an increasingly global context. Past studies of transnationalism and emotion have emphasized how migrants use the resources available to them to connect both home and away through home town associations (Fitzgerald 2008), remittances (Yeoh, Leng, Dung and Yi'en 2013), through household strategies (Parrenas 2005) and increasingly by using technology (Madianou and 
Miller 2012; Peng \& Wong 2013). Emotions are no exception and love is on the move too Ahmed 2003; Pratt 2012). Studies are beginning to ask what effect loving at a distance has on people, their emotional discourses and practices (McLeod and Burrows 2012; Svasaek and Skrbis 2007; Beck and Beck-Gernsheim 2014).

2.2 Globalization theorists such as Beck (2011) and Giddens (2003) often use transnational families as examples in their work to argue that people, under cultural global influences, are becoming more individualized and disembedded from social relations. Families are mobile and become untethered from their local extended kinship networks, neighbours and culture. For Beck and Giddens, individuals are at risk because their social networks and cultures are so spread out that social ties are thin and at a distance. One is 'deterritorialized' (Appadurai 1998) and disembedded from collective notions of culture and the social ties that come with it.

2.3 Alternatively, Anthony Elliott and John Urry (2010) argue that culturally people are more mobile and more global in focus, but they still maintain strong emotional networks. The big change, they argue, is that now people depend more on mobile technologies to do so. Larsen et. al. show that strong ties can exist at a distance and that new ties in one's immediate vicinity are created through face to face interactions as well as travel, internet, and mobile approaches to social networks $(2006,279)$. They argue that under cultural globalization people have not compressed, but enlarged, social network geographies (2006:280). However, global-local links, networks, and cultural embeddedness and belonging are mediated primarily at a meso level of social analysis through people's emotional links to others primarily to the ones they love and who love them.

2.4 Much of the past literature has focused quite clearly on issues of 'care' often in a market setting (Parrenas 2005). Brooks and Simpson (2013) show how the context of migration is gendered and shapes decisions for women about their migration shaped by many factors such as poverty, employment and lifestyle opportunities (p. 106). While Brooks and Simpson (2013) illustrate relationships between emotions, migration, gender and reflexivity, they do little analysis of the effect of distance and migration on emotions themselves.

2.5 This article extends this focus on emotions to consider not just care or belonging, but also 'romantic love' that many social actors feel exists (and should exist) outside of obvious market forces. The data presented here then illustrate the strength of focusing on love as a way to understand the distinction between understandings and practices of love in which love is the basis for enduring distance, but also the motivating factor to social action - namely migrating for love. I do this in order to offer a more microanalysis of what happens to emotions within transnational social relations to ask 'what role does distance play in shaping what is even defined as love?'

2.6 Therefore, I take a slightly different approach to understanding the impact of globalization on culture and emotion practices by applying these theories to a more micro level social analysis focusing on connections between intimate spaces (homes) and on the subject of love as a cultural idea and practice, following scholars who have thought about love in this way (Ahmed 2003; Probyn 2010). In doing so, I hope to better understand the transnational intimate practices and experiences created when partners within a family come from different countries, cultures, languages, and sometimes religions, races/ethnicities and cultural backgrounds and come together to create and maintain transnational emotional ties across vast times and spaces.

2.7 The data presented here are an illustration of social relations within transnationalism structured clearly by macro economic forces, meso state level forces, but also focusing on micro and very intimate interpersonal understandings and practices of love. Emotions are not simply convenient resources to be called upon to explain transnational family life; they are constitutive of the transnational family itself (Skrbis 2008, 242). Within transnational families, there is much effort put into the management of transnational emotions such as loneliness, homesickness, support, and obligation (Ryan 2008) and this is combined often with increasing or decreasing emotional attachment to place (Svasek 2010) both in emotional discourse and practice. Transnational families have always found ways to communicate their emotions across vast temporal and spatial distance and for many, the definition of their love as 'strong' and enduring, shaped the decision to migrate. In my sample of interviews, couples often met studying, working or travelling abroad and then in many instances were subsequently involved in long distance relationships when visas or jobs ran out. For many couples this involved making a decision to migrate to one or the other partner's countries and cultures not only for economic reasons or to improve their standard of living, but for love. This decision was not instantaneous for many, it almost always involved leaving others that they loved (parents, siblings and home places) behind possibly creating new emotional connections and obligations far away. 


\section{Methods}

3.1 The data in this chapter come from ethnographic narrative qualitative interviews with mixed international couples and their family members who are or have lived in the Republic of Ireland. Ethnographic interviews are qualitative in depth interviews, which are conducted and take into consideration the social context in which they are conducted. The interviews were flexible and informal so that participant observation could also be done. In this instance, the participants were interviewed (either one or both members of the couple) within their households (where possible) often when their partner and/or children were around. While this was often noisy and at times chaotic, it also meant that we ${ }^{2]}$ could not only ask about loving practices, but also to observe those practices first hand. This also meant that 'tacit' notions of love, which interviewees felt were hard to describe, could be observed first hand such as 'caring gestures' like making a cup of tea for their partner, etc.

3.2 Sampling of interviewees was done through a national call through the Educate Together (the only multidenominational) Schools in the Republic of Ireland asking for participants from international/transnational families. Ads were also placed in gay/lesbian, ethnic migrant, and interracial print and on line magazines, newspapers and newsletters to recruit interviewees. Announcements were also placed in newsletters of relevant community based organizations such as the Bilingual Forum Ireland. I also contacted the former founder of the Harmony organization, Marian Tannam. Harmony was a community based organization that existed in the 1980s and 1990s in Ireland for interracial families of which many members were predominantly white Irish women who had had children with black African and Caribbean men and who were raising mixed children in Ireland. From this meeting, snowball sampling was used to contact former members for interview. While the sample of interviewees is not generalizable, I did take strides to insure some regional, gender and ethnic and class diversity in the sample.

3.3 36 interviews were conducted through the language of English in 2010-2012 with same sex and heterosexual couples (ages 18-61) and children when possible, from Ireland, France, Canada, US, UK, Italy, India, Sri Lanka, Algeria, Poland, Turkey, Zimbabwe, Australia and China living in Ireland, the UK and the US. Interviewees in Ireland were residing in: Cork, Kildare, Galway, Tipperary, Dublin and the surrounds.

3.4 All interviews and ethnographic notes were digitally recorded and then transcribed. The project complies with institutional ethical approval guidelines and all interviewees granted informed consent. To protect the interviewees, all of the data has been anonymized. The names used are pseudonyms and any geographic or personal data that could identify the interviewees has been changed to protect their anonymity.

3.5 The 'extended case method' (Burawoy 1998) was used to analyse the data presented here grounding the analysis in the building of theory about distance and emotion based on the literature above on transnationalism and emotion. By grouping the data by themes that other theories could not explain, I build new, and hopefully better, theory by examining the themes highlighted in this data.

3.6 In the data, thirty-one of the interviewees were a part of a heterosexual couple and five were a part of a same sex couple. All couples had one international partner or spouse who described themselves as 'international' and not Irish. The chart below summarizes the background information on the interviewees:

\section{Table 1:}

\begin{tabular}{|c|c|c|c|c|c|c|c|c|}
\hline ID & Gender & $\begin{array}{l}\text { Country of } \\
\text { Origin }\end{array}$ & Occupation & $\begin{array}{c}\text { Relationship } \\
\text { status }\end{array}$ & Ed. level & Age & $\begin{array}{c}\text { Gender/nationality } \\
\text { of Partner }\end{array}$ & Children \\
\hline 1 & Female & Ireland & Shop owner & Divorced & High school & 60 & Male/Nigeria & $\begin{array}{c}2 \text { (in their } \\
20 \text { s) }\end{array}$ \\
\hline 2 & Male & Ireland & IT & Married & University/college & 32 & Male/USA & 0 \\
\hline 3 & Male & USA & Finance & Married & University/college & 34 & Male/Ireland & 0 \\
\hline 4 & Female & France & Teacher & Married & University/college & 42 & Male/Ireland & $\begin{array}{c}2 \text { (9 and } \\
12 \text { years } \\
\text { old) }\end{array}$ \\
\hline 5 & Male & Ireland & Business & Married & University/college & 60 & Female/France & $\begin{array}{c}2 \text { (9 and } \\
12 \text { years } \\
\text { old) }\end{array}$ \\
\hline
\end{tabular}




\begin{tabular}{|c|c|c|c|c|c|c|c|c|}
\hline 6 & Female & USA & $\begin{array}{l}\text { Stay at home } \\
\text { mom }\end{array}$ & Married & High school & 40 & Male/Ireland & $\begin{array}{c}4(2,9, \\
11 \text { and } 14 \\
\text { years old })\end{array}$ \\
\hline 7 & Male & Ireland & Unemployed & Married & $\begin{array}{l}\text { Some high } \\
\text { school }\end{array}$ & 42 & Female/USA & $\begin{array}{c}4(2,9, \\
11, \text { and } \\
14 \text { years } \\
\text { old) }\end{array}$ \\
\hline & Male & India/Ireland & Student & Single & some college & 18 & Male/Belgium & 0 \\
\hline & Female & Ireland & CBO worker & Co-habiting & Some college & 31 & Male/Poland & $\begin{array}{l}1 \text { (3 year } \\
\text { old) }\end{array}$ \\
\hline 10 & Male & Poland & Construction & Co-habiting & High school & 33 & Female/Ireland & $\begin{array}{l}1 \text { (3 year } \\
\text { old) }\end{array}$ \\
\hline 11 & Female & Sri Lanka & Academic & $\begin{array}{l}\text { Arranged } \\
\text { marriage }\end{array}$ & University/college & 34 & Male/India/Ireland & 0 \\
\hline 12 & Male & India/Ireland & Academic & $\begin{array}{l}\text { Arranged } \\
\text { marriage }\end{array}$ & University/college & 36 & Female/Sri Lanka & 0 \\
\hline 13 & Male & Ireland & Business & Married & Some college & 54 & Female/Poland & 0 \\
\hline 14 & Female & Poland & $\begin{array}{c}\text { Shop } \\
\text { assistant }\end{array}$ & Married & High school & 39 & Male/Ireland & 0 \\
\hline 15 & Female & UK & $\begin{array}{l}\text { Teaching } \\
\text { assistant }\end{array}$ & Married & High school & 38 & Male/Ireland & 0 \\
\hline 16 & Female & $\begin{array}{c}\text { Chinese } \\
\text { American/USA }\end{array}$ & IT & Married & University/college & 42 & Male/Ireland & $\begin{array}{c}3(4,7, \\
\text { and } 9 \\
\text { years old })\end{array}$ \\
\hline 17 & Male & Ireland & IT & Married & University/college & 44 & $\begin{array}{c}\text { Female/Chinese } \\
\text { American }\end{array}$ & $\begin{array}{c}3(4,7 \\
\text { and } 9 \\
\text { years old })\end{array}$ \\
\hline 18 & Male & Spain & Translator & Co-habiting & Some college & 23 & Female/Ireland & Expecting \\
\hline 19 & Female & Ireland & Business & Co-habiting & University/college & 27 & Male/Spain & Expecting \\
\hline 20 & Male & Zimbabwe & $\begin{array}{l}\text { Development } \\
\text { worker }\end{array}$ & Married & High school & 35 & Female/Ireland & $\begin{array}{l}1 \text { (3 year } \\
\text { old) }\end{array}$ \\
\hline 21 & Female & Ireland & $\begin{array}{l}\text { Development } \\
\text { worker }\end{array}$ & Married & $\begin{array}{l}\text { University/ } \\
\text { college }\end{array}$ & 33 & Male/Zimbabwe & $\begin{array}{l}1 \text { (3 year } \\
\text { old) }\end{array}$ \\
\hline 22 & Female & Ireland & Teacher & Married & College & 61 & Male/USA & $\begin{array}{l}2 \text { adult } \\
\text { children }\end{array}$ \\
\hline 23 & Female & Turkey/France & $\begin{array}{l}\text { Insurance } \\
\text { sales }\end{array}$ & Married & Some college & 33 & Male/Turkish/Ireland & $\begin{array}{l}1 \text { (5 year } \\
\text { old) }\end{array}$ \\
\hline 24 & Female & USA & Teacher & Married & University/college & 26 & Male/Ireland & 0 \\
\hline 25 & Female & UK & IT & Married & University/college & 41 & Male/Ireland & $\begin{array}{l}1 \text { (2 year } \\
\text { old) }\end{array}$ \\
\hline 26 & Male & Canada & IT & Married & University/college & 25 & Female/Ireland & 0 \\
\hline 27 & Male & Ireland & Finance & Married & University/college & 57 & Female/China & $\begin{array}{l}2 \text { adult } \\
\text { kids }\end{array}$ \\
\hline 28 & Female & Chinese & $\begin{array}{c}\text { Stay at home } \\
\text { mother }\end{array}$ & Married & Some college & 34 & Male/Ireland & $\begin{array}{l}1 \text { (4 year } \\
\text { old) }\end{array}$ \\
\hline 29 & Female & French & Writer & Co-habiting & University/college & 35 & Male/Ireland & $\begin{array}{c}2 \text { (2 and } \\
4 \text { years } \\
\text { old) }\end{array}$ \\
\hline 30 & Female & Ireland & Civil servant & $\begin{array}{l}\text { Co- } \\
\text { abiting/engag }\end{array}$ & Some College & 32 & Female/Australia & 0 \\
\hline 31 & Female & Ireland & $\begin{array}{c}\text { Shop } \\
\text { assistant }\end{array}$ & Divorced & High school & 45 & $\begin{array}{l}\text { Male/Hong Kong } \\
\text { Chinese }\end{array}$ & $\begin{array}{l}1 \text { adult } \\
\text { child. }\end{array}$ \\
\hline
\end{tabular}




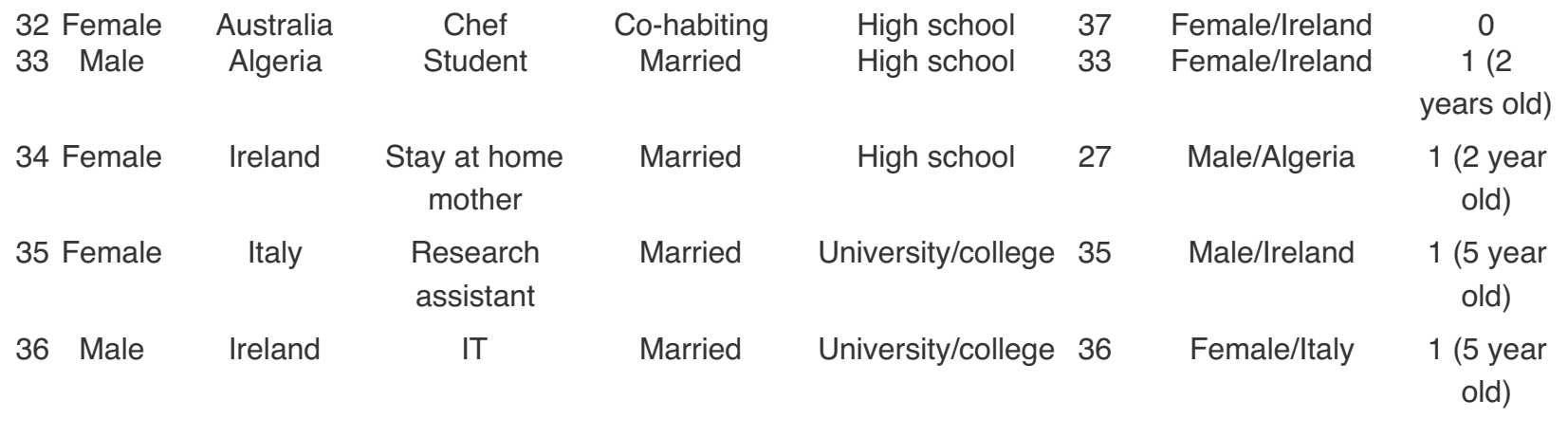

3.7 While these interviews, due to sampling methods, cannot be generalized to all inter couples in Ireland, they do mirror demographic and gendered trends in intermarriage in Ireland.

3.8 The research here targeted intermarriage and transnational couples to discuss love and loving practices as a way to better understand how concepts of love might be changing in this late modern and global moment. If love is socially constructed and grounded in meanings from a local context, how then do conceptions of love change when in contact with new and different concepts of love? Interestingly, most of the concepts of love discussed in the interviews were homogeneous, often based on a heteronormative narrative of one true love, loyalty and authenticity. This was the framework of meaning used by the couples (even same sex couples) to talk about the role played by distance in their relationships. There was a strong link between the abilities of the individuals interviewed to reflect on their emotions and know they were loved as well as 'feeling' love themselves.

3.9 They often used the awareness of this emotion to guide their decisions about where to live. Emotions then were at the base of the reflective process (Holmes 2010), which in turn had very practical consequences in everyday life - like deciding to migrate to live in another country. In addition, the understanding of love (emotion) shaped love practices in two clear ways. First, may interviewees discussed enduring distance for love, even arguing that love was defined by the 'missing' and 'trust' at a distance. Second, couples often used their understandings of love to motivate them to cross great distances and make great sacrifices, including leaving behind other types of loving relationships (siblings, parents, friends) in order to migrate for love. There was also a relationship, at times, between enduring distance for love turned into crossing distance for love - when the relationship was deemed serious enough to warrant relocation or because the individuals in the relationships 'couldn't take the distance' anymore. Relocation though was not possible for all, particularly same sex couples in Ireland before May 2015, and the state played a role in policing, legitimating and managing 'love' in some of the couples interviewed here. It is from these discussions that that the following data is drawn.

\section{Crossing Distance for Love}

4.1 One of the main ways that love was discussed in the interviews was in the narratives around the decision to migrate or move in order to be with a partner. This was complicated in many of the couples interviewed because of migration laws within the EU and Ireland and particularly for same-sex couples, who, at the time of interview, did not have a right to civil partnership, making it almost impossible to bring non-Irish partners with them legally into the country. Most of the couples interviewed had a migration story that was not based on money or work considerations, but for love and family. In this sense, the decision to migrate to Ireland for many of them was not a 'rational' decision in the sense of a rational economic choice to maximize their economic utilities, but instead, a move motivated by the heart and emotional rationality for their happiness. Most of these couples framed this as having made great sacrifices, often leaving jobs, higher standards of living, other loved ones, cultures, religions, foods, and languages behind for love. Many in the sample spoke about the ability to make these types of sacrifices, in a spirit of generosity, not looking for payback from their partner. Migration was explained as a commitment to the love they felt for the other person, which, in turn, motivated their mobility. It was also, importantly, for many, the indication that they were truly in love. Mary, an Irish woman in her midthirties, told of how she went to Malawi do to development work with an Irish agency. While Mary was working on secondment in Zimbabwe she met Jonah, a local development worker, and they realised that they were meant to be together. This was difficult from the start not only because of cultural differences, but because Mary was set to return to Malawi and then to Ireland, which would mean a separation. Jonah (from Zimbabwe) and Mary (Irish) told us, without prompting, in the interview that they were in love. We then asked them, 'how did you know you were in love?' They explain:

Jonah: We didn't. We still don't (laughing heartily)

Mary: For me, I couldn't say it was love at first sight because we met and then very quickly, but I think it was very 
instant that I felt the romance of whatever it was, for me it was, because it wasn't on my plan. I wasn't thinking I might meet someone here. I had had lots of other relationships for years and then I definitely wasn't thinking 'oh I wonder will I meet somebody in Malawi and fall in love.' You know it just wasn't on my mind, so I did feel straight away that we just seemed to be together.

Jonah: I thought that when I was jumping on a bus to follow her to Malawi in the middle of the night. I was going to a place where I knew no one. All I had was a phone number and I was following Mary over to this place and I was thinking 'what the hell are you doing?' but I came anyway!

Jonah goes on to describe how the ability to just get up and follow Mary to Malawi, where she was working, and then to Ireland, proved to himself that their love was real - it was meant to be. They agreed that they couldn't endure a long distance relationship and that in Jonah's words they 'couldn't live without each other' so they made the decision to relocate together to Ireland. Love was the motivation for his migration, not money or work, and was defined through the social action of 'taking a leap of faith in love,' which involved imagining a future together. Jonah and Mary explained that they knew that some people might think that they were at best irrational, or at worst crazy, to make such a decision to 'follow the heart' but they also felt that love provided a socially acceptable explanation of why Jonah had moved from Africa to Ireland. The social fact that they felt they needed an explanation for others, points to the increasing scrutiny that mixed couples in Ireland may face in recent crackdowns on sham marriages, which are often assumed to be interracial and not based on 'real' love. It also belies the power imbalance that many assume within these types of relationships where one partner comes from a developing country and the other from a wealthier country. They think that 'love' is suspect and that the motive for migration is just about improving one's standard of living and not about love.

Likewise, others made quick decisions about migration and marriage because of their love for each

other. The connections between marriage and migration laws, meant that the desire to be together and live in the same place led to constrained marriage choices and in some cases marriage was needed to 'ease' the mobility of partner, but this choice was not always available to all (same sex couples) and not all decisions around marriage and migration were clear cut. Conal, who is Irish, is married to Sau Ling, who is Chinese American. They are both in their 40s, have three children together and live in the UK after having lived in Ireland for 5 years. Conal and Sau Ling met while they were both studying science in the USA. Conal discusses the decision to migrate back to Ireland and the sacrifices that Sau Ling made in moving to Ireland to be with him. He speaks openly about how the visa restrictions in Ireland played a role in their decision even to get married in the first place. This is an example of where the personal and emotional decision to migrate is strongly shaped by state practices through marriage, migration and citizenship law which determine who can love whom and who can migrate. He explains:

Interviewer: So, how did you make the decision to get married?

Conal: Well, I think that was partly influenced by the visa problem and moving here.

Interviewer: Yes she told me, you came and then you came back together or something, right?

Conal: Well, I came back (to the US) to get her.

Interviewer: I think that is what she said, you came back to get her.

Conal: I came back so that we could come back here (Ireland) together. I mean it wasn't that she couldn't have travelled on her own. But there were all sorts of difficulties with her visa. I think if we had been against getting married we could have negotiated. It turns out that we could even have gotten engaged. . . But we didn't even ask about that so I think at heart we sort of wanted to get married and this whole thing about the visa problem was just a way of permitting ourselves to do that. It was quite a decisive move, we hadn't known each other that long, there had been all this messing with (past girlfriend) and it was beyond that. We had known each other in this very particular context. I had been in Boston for a year, Sau Ling was coming towards the end of her PhD, you know, there were all sorts of reasons why it was a foolish thing to do. So when you are making a risky move you like to show... it is nice to be able to point to some other reason for doing it and I think that is very much the case with what we say about why we got married. We say we got married for visa reasons but I am not really sure that that was the crucial point... (italics added by author for anonymity).

4.4 For Conal and Sau Ling, not having a visa for Ireland from the US provided a rationale for getting married i.e. because they 'had' to for the visa. Even though he knows that it could be interpreted as a 'foolish thing to do' to get married because they hadn't known each other for very long, Conal also explains that because they were in love and because the state required marriage for a visa, they were happy to get married. It is interesting that although self-defined 'free spirits,' both himself and Sau Ling did care what other people thought of how they came to be married and living in Ireland. Conal was particularly sensitive about the racialised accusation that their marriage wasn't 'for love' or 'for real' but just to get her into the country because she was Chinese American. He explains that irrational action, like getting married quickly for mobility, will be more comprehensible and accepted by others if explained away by love as the motivator. In the end, both Conal and Sau Ling did not tell their parents they were getting married. They eloped and married at a registry office in the 
US and told their parents afterwards. This was in part driven by the fact that theirs was an interracial/intercultural marriage and neither set of parents were involved in the marriage ceremony. Their parents objected mainly on the grounds that it was not a rational decision to get married so quickly in order to be able to migrate legally to Ireland. Distance and migration for these both couples above, served as proof that their love was a strong enough reason to relocate to be together.

\section{Love at a Distance}

5.1 Not everyone was so lucky though and it was common that many of these mixed couples/families had to love for a time (or even over long periods of time) from a distance. Many couples spoke of the time they spent apart as a 'test of their relationship' over both time and distance. Some felt that being separated and loving from a distance was the real test of their love. Having a long distance relationship was having the same, basically unchanging, relationship that was just temporarily over distance, but one that survived the challenge of being separated. They felt that the distance between partners (again both emotionally and physically) made their relationship stronger. Some felt that distance made them appreciate the time spent together more. While others explained that distance allowed them to have their own space and independence, while still maintaining close emotional ties, but trust had to be high in order for this to work.

5.2 Felipe, from Spain (in his mid twenties) and Orla (from Ireland in her late twenties) who met working together in business in Spain spoke about the issue of separation when Orla relocated to Ireland for a better job and the role that distance played in their relationship.

Felipe: Love is something that you feel; you know it (laughing, both)

Orla: I think the fact that we were so far away from each other and we had to - we knew there was no way we were going to be able to live together in a short space of time. We knew we were going to have to be a long, long time separated but it wasn't a factor. It wasn't an issue, like it didn't bother me like. I was perfectly happy. I remember all my friends saying to me 'you are mad, he's off over there and you are not seeing him and you don't know what he's up to?' but we just had this kind of trust and we talked every day on the phone religiously. I don't know, I suppose there was this feeling of trust.

Interviewer: Is that a big thing, trust, when there is a big distance?

Orla: It is a huge thing, huge huge factor I think but I never had any doubts, that's how I think I knew I was in love, because I felt comfortable. I felt like I could trust him and he always rang me when he said he would and things like that.

Felipe: I suppose that feeling when there is so much distance but you really don't feel any distance, you feel very close you feel closer than you ever felt to any other person who could be around to you so yes, I suppose nobody tells you you are in love, you just feel it, you know.

5.3 Trust, especially over distance, not only was a test of love, it defined love, and was a signal, upon selfreflection, that Orla and Felipe knew they were 'in love'. Distance was a part of the social construction and criteria of love. This psychic confirmation of love involves a deep level of emotional reflexivity (Holmes 2010). As Burkitt (2012) explains,

\footnotetext{
...we are emotionally engaged with others in our social interactions and these emotional engagements regularly motivate our reflexivity through the reflexive dialogue we privately stage with the image and voice of others (Burkitt 2010a). In reflexive dialogue, feelings and emotions are not just attendants to reflexivity; they are the basis and motive for reflexive thought (p. 469).
}

5.4 Applying this to the concept of love, as Felipe says, 'you just know' you are in love. You know, because you have a definition or criteria of what love is in your emotional experience and these are compiled, in part, from collections of meanings that you have taken from what other people define, tell you and practice as 'love'. These are what I call the emotional cultural casings - socially constructed containers in which we hold our ideas of 'what love is' and how to 'practice' that love (offering support), which we learn largely from social interactions with others. We then take these ideas and practices of love and think about them within ourselves to come to our definition of what love is, which is based and confirmed almost entirely on how we feel (emotions).

5.5 Sinead, (Irish and in her 40s), is now divorced from her husband Hong, who is also in his 40 s and is Chinese from Hong Kong originally. They met in Dublin in their 20s and formed an interracial couple, which was unusual at the time. Despite their divorce, Sinead talks about their 20-year marriage and their first meeting with nostalgia. Again, she spoke candidly about how she knew she was in love with Hong early in the relationship. She says, 
I just realised I was in love when I missed him. He had gone away for two weeks - had gone back to his own country - and I was literally heartbroken. His mother had been sick and I was so afraid that his mother was going to die and I wouldn't see him again and I think that's when I realised that I was in love...I realized when I went to the airport to meet him that I really did love this person and I just felt so happy to see him. I just felt so incomplete without him.

5.6 The distance and absence did really make her 'heart grow fonder' and with his absence over time and space, Sinead realized that she was indeed really in love with him. It was the distance that made her think to herself, 'I do love him truly.' We then asked her about their reunion upon his return. She continues, 'I was ecstatic. I just felt relieved that everything was going back to normal and we could just carry on with our lives then and I suppose him coming back, the fact that he did come back maybe meant a lot to me at the time that he might feel as deeply about the relationships as I did.'

5.7 Others also distanced themselves from others they loved (parents, friends, etc) because of love.

Leaving, moving or migrating because of love, as a sign of commitment was common in the interviews. There is a large literature (Harvey 1997) on the anchor (job seeking) and trailing spouse (usually a woman), but these studies tend to focus on the individual migrants. However, there are many other factors that shape the decision to migrate beyond individual capital such as: location of extended family members (increasingly NOT in the home country), institutional reasons (we could migrate there, they have jobs, they will grant citizenship, they will legally recognize our partnership) or access to technology and cheap flights (we could get good broadband speed and Skype everyday or there is a direct flight everyday).

5.8 Many felt that their partner migrated not for money, but primarily as a sign of love and commitment. Again, Jonah's migration to Malawi to be with Mary continued to be questioned by others when he agreed to follow her to Ireland where they now live with their five year old mixed-race daughter.

Mary: Yes, we got engaged in the August after we met the previous November. We were together from the June (2000) and the big commitment was Jonah moving here and getting married.

Jonah: I was lucky getting a job straight away, got me on the good side of the family (laughing).

5.9 Mary's parents were highly skeptical of Jonah - thinking that he was just marrying Mary to get a visa to Ireland. Mary spoke openly about how marrying Jonah, she was really sticking her neck out. She describes how her parents repeatedly asked her if he was married with loads of children in Africa. In part, their skepticism of Jonah was based on the fact that he was from far away (culturally and geographically) and that they didn't know him well. Time, and his ability to work and provide for his family, in this case, allayed their fears. This was important to both Mary and Jonah, but it did not mean that Jonah did not have continuing family love and obligations back home. As McLeod and Burrows (2012) point out:

In forming an intimate relationship with someone from a different country, it is striking how the compulsion towards a duty of care for often remote others begins to fundamentally alter structures of feeling (pg. 372).

5.10 While Jonah, like many of the interviewees here, migrated to make one loving relationship work better, in turn they create new felt obligations to maintain or create stronger emotional bonds to compensate for their distant location (Mc Leod and Burrows 2012:374).

\section{Conclusion}

6.1 From the data presented here, one can see that love was defined as a particular type of emotion and one that could motivate strong social action such as moving one's whole life overseas for a partner. It also was 'worth sticking your neck out for' across racial lines and in the face of skepticism from families. The reason it was worth it and could motivate such (and sometimes sudden) mobility decisions was because there were high levels of trust and the ability to see a 'future' together that was worth working/sacrificing for. The belief in the strength of their love, even in the face of racism, marriage and migration legal challenges and cultural adaptations, made people feel that their love would last and should be recognized socially.

6.2 Distance played a particular role in both confirming and defining love for many of the relationships described here. Within the decision making about how to negotiate distance, there again was a strong sense of trust and reliability, and rational calculation, which took place within an emotionally reflexive process that this emotion (love) and this person could be depended upon. That belief was built in many ways into the relationship itself and formed the basis of the construction of love institutions (marriage) based on it. Love, interestingly, also provided a socially acceptable reason, although sometimes considered an irrational or rash decision, for migrating across great distances (both geographically and culturally). People could understand why and how they could bring themselves to leave all they love behind for love. 
Here in the data, we see love as a motivation to migrate/move following someone to the 'ends of the earth' (Jonah) because they trust that person, hope that their love will last and is able to underpin future plans. Even distance, which in the past may have been a major obstacle to love, became part of the process of defining the emotions that participants had as 'love' either when they didn't feel the distance because of love (like Felipe) or when the distance and absence of their partner made them realize that it was love and that they felt incomplete without them (like Sinead).

6.4 Emotions are at the core of reflexive processes, which in this data, led to decisions to negotiate distance by enduring and crossing. The decisions to endure and/or cross spatial distance in the name of love was embedded within the emotional cultural casings that social actors understood and practiced. Distance was both a confirmation of love when endured and the motivation for love when one migrated as a commitment to it. These two different emotional responses shaped social action in two different ways, but both serve to illustrate how space, and distance in particular, shape how we understand and practice love in an increasingly global world.

\section{Notes}

Many thanks to Natàlia Cantó Milà, Swen Seebach, the Sociology of Emotions Research Network and the anonymous reviewers and editors for helpful comments and suggestions.

Many thanks to Brenda Farrell and Pierce Richardson, research assistants, for help with conducting and transcribing some of the interviews.

\section{References}

AHMED, S. (2003) "In the Name of Love."Borderlands e-journal 2:3.

APPADURAI, A. (1998) Modernity at large: cultural dimensions of globalization Minneapolis, MN: University of Minnesota Press.

BALDASSAR, L. (2008) "Missing Kin and Longing to be Together: Emotions and the Construction of CoPresence in Transnational Relationships". Journal of Intercultural Studies 29, p. 247-266. [doi:10.1080/07256860802169196]

BECK, U and Beck-Gernsheim, E (2014) Distant Love. Cambridge, UK: Polity Press.

BECK, U. (2011) "The Global Chaos of Love" talk at the London School of Economics. 23 February 2011.

BECK-GERNSHEIM, E (2007) Transnational Lives, Transnational Marriages: A Review of the Evidence from Migrant Communities from Europe. Global Networks 7, p. 271-288. [doi:10.1111/j.14710374.2007.00169.x]

BROOKS, A. and Simpson, R. (2013) Emotions in Transmigration: Transformation, Movement and Identity. Hampshire, UK: Palgrave Macmillian.

BURAWOY, M. (1998) "The Extended Case Method" Sociological Theory.16, 1:4-33. [doi:10.1111/07352751.00040]

BURKITT, I (2012) Emotional Reflexivity: Feeling, Emotion and Imagination Dialogues. Sociology. 46(3) p. 458472. [doi:10.1177/0038038511422587]

BURKITT, I. (2010a) Dialogues with self and others: Communication, miscommunication, and the dialogical unconscious. Theory \& Psychology20(3): p. 305-21.

ELLIOTT, A and Urry, J (2010) Mobile Lives. London: Routledge.

FITZGERALD, D. (2008) "Colonies of the Little Motherland: Membership, Space and Time in Mexican Migrant Hometown Associations." Comparative Studies in Society and History50, p. 145-169. 
GIDDENS, A. (2003) Runaway World: How Globalization is Reshaping Our Lives.London: Routledge.

HARVEY, M. (1997) "Dual-Career Expatriates: Exceptions, Adjustments and Satisfaction with International Relocation". Journal of International Business Studies 28: p. 627-658.

[doi:10.1057/palgrave.jibs.8490114]

HOLMES, M (2010) Emotionalization of Reflexivity. Sociology. 44(1) p. 139-154. [doi:10.1177/0038038509351616]

LARSEN, J., Axhausen, K.W., and Urry, J. (2006) "Geographies of Social Networks: Meetings, Travel and Communications." Mobilities 1, p. 261-283. [doi:10.1080/17450100600726654]

MADIANOU, M. and Miller, D. (2012) Migration and New Media: Transnational Families and Polymedia.London: Routledge.

MCLEOD, D. and Burrows, R. 2012. "Home and away: Family matters in the lives of young transnational couples" Journal of Sociology. 50(3) p. 368-382. [doi:10.1177/1440783312462164]

PARRENAS, R. (2005) "Long Distance Intimacy: Class, Gender and Intergenerational Relations between Mothers and Children in Filipino Transnational Families." Global Networks 5, p. 317-336.

[doi:10.1111/j.1471-0374.2005.00122.x]

PENG, Y. and Wong, A. M.H. (2013) "Diversified Transnational Mothering Via Telecommunication: Intensive, Collaborative and Passive" Gender and Society, 27 (4) p. 491-513. [doi:10.1177/0891243212473197]

PRATT, G. (2012) The Global and the Intimate. New York: Columbia University Press.

PROBYN, E. (2010) "Researching Intimate Spaces" Emotion, Society and Space.3,1 p. 1-3.

RYAN, L. (2008) "Navigating the Emotional Terrain of Families "Here" and "There": Women Migration and the Management of Emotions." Journal of Intercultural Studies 29, p. 299-313.

[doi:10.1080/07256860802169238]

SKRBIS, Z. (2008) "Transnational Families: Theorising Migration, Emotion and Belonging." Journal of Intercultural Studies 29, p. 231-246. [doi:10.1080/07256860802169188]

SVASEK, M. (2010) "On the Move: Emotions and Human Mobility." Journal of Ethnic and Migration Studies36: p. 865-880. [doi:10.1080/13691831003643322]

SVASEK, M. and Skrbis, Z. (2007) "Passions and Powers: Emotions and Globalisation."Identities: Global Studies in Culture and Power 14, p. 367-382. [doi:10.1080/10702890701578415]

YEOH, B. S.; Leng, C. H.; Dung, V. T., and Yi'en, C. (2013) "Between two families: the social meaning of remittances for Vietnamese marriage migrants in Singapore." Global Networks. 13(4) p. 441-458. 